\title{
SOMLYÓDYNÉ PFEIL EDIT: ÖNKORMÁNYZATI INTEGRÁCIÓ ÉS HELYI KÖZIGAZGATÁS
}

\author{
(Dialóg Campus Kiadó, Budapest-Pécs, 2003, 295 o.)
}

\section{MEZEI CECÍLIA}

Európai uniós csatlakozásunk küszöbén mind jobban felerösödnek a közigazgatás korszerüsítésére, hatékonyságának növelésére, az önkormányzati integrációs eszközök átgondolására ösztönzö igények. Fontos lenne, hogy olyan közigazgatási rendszerrel lépjünk be az Unióba, amely hatékonyabb, szervezettebb, felkészültebb az igazgatási és egyéb feladatellátás területén. Közigazgatási rendszerünk jövőjének tervezgetése során nem mehetünk el olyan alapelvek mellett, mint a hatékonyság, a partnerség, a szubszidiaritás vagy a decentralizáció, ahogyan az önkormányzati integrációs (egyesülési, egységesülési, együttmúködési) tendenciák mellett sem. Ezért érdemes kézbe venni Somlyódyné Pfeil Editnek a Dialóg Campus Kiadó gondozásában megjelent, Önkormányzati integráció és helyi közigazgatás címủ könyvét.

Somlyódyné Pfeil Edit neve az elmúlt évtizedben szorosan összefonódott az önkormányzati társulások kutatásával, hiszen számos tudományos cikkben tájékoztatta az olvasóközönséget az időnként változó hazai szabályozási kömyezet hatásairól, vagy éppen a témához kapcsolódó OTKA-kutatások következtetéseiröl stb. Ez a könyv is fényes bizonyítéka annak, hogy Pfeil Edit a téma hozzáértő kritikusa, avatott szakértője, aki ráadásul kitủnő elemző képessége mellett nem fél az innovatív problémamegoldástól, a kiútkereséstöl sem.

A könyv a hazai közigazgatás-szervezési problémákkal foglakozik, kiemelt figyelmet szentelve azoknak az önkormányzati társulásoknak, amelyek képesek lehetnének az integrációs ür betöltésére a közigazgatási rendszerünk alapszintjén. A Studia Regionum sorozat elemeként megjelent mü igényes kivitelezésével is jelzi, hogy a szerzötöl már megszokott, stílusos, alapos munkát vehetünk a kezünkbe, amely időszerü témaválasztása révén széles érdeklödésre tarthat számot. A könyvet eredménnyel forgathatják mind a téma kutatásában vagy tanulmányozásában érdekelt oktatók, hallgatók, mind pedig a kutatótársak.

Hiánypótlónak kell tekintenünk a müvet, hiszen a hazai szakirodalomban sehol sem találkozhatunk az önkormányzati integrációs formák nemzetközi összehasonlító elemzésével, a hazai önkormányzati társulások helyzetét az önkormányzati integráció szemszögéből értékelö, a hazai önkormányzati együttmúködések jövőjét több dimenzióban felmérö, ilyen sajátos szemléletmódú, összegzö munkával. Bátor és egyúttal sikeres vállalkozása volt a szerzỏnek, hogy ezt az összetett kérdést ilyen sokoldalú, multidiszciplináris megközelítésmóddal tárgyalja. A feladatvállalás magával hozta az alkalmazott módszertant is, amely az empirikus és az elméleti metodikát egyaránt ötvözi. A kötet illusztrálásaként felvonultatott térképek és táblázatok 
annak bizonyítékai, hogy a szerzö minden állítása, minden következetése mögött komoly kutatómunka áll.

A szerző segítségével térben és időben hosszú utat teszünk meg, míg eljutunk a jelenlegi hazai önkormányzati integrációs helyzet értékeléséhez. Az idődimenzió föként a hazai és a német integrációs gyakorlat történeti bemutatásával tágul ki, olyannyira, hogy bizonyos fejezetek (2-4.) közigazgatás-történeti kitekintéssel gazdagítják a könyv mondanivalóját. A térbeli kitekintés során azonban nem elégedhetünk meg csupán a hazai és a német gyakorlat ismeretével. A szerző alaposságát dicséri, hogy a problémafelvetésen túl kiemelt figyelmet szentel a problémamegoldásra is, amelyhez az osztrák, a svájci, az olasz, a spanyol és a francia integrációs megoldások bemutatását használja fel.

A tanulmány elején a szerző az integráció fogalmát járja körül, felvonultatva az önkormányzati integrációs lehetöségek széles skáláját. Amikor a hazai közigazgatási rendszer értékelésekor hatékonysági, eredményességi kérdéseket feszegetünk, vagy éppen a tényleges decentralizáció hiányát kifogásoljuk, az önkormányzati együittmüködések és - azon belül leginkább - az önkormányzati társulások olyan megoldási lehetőséget kínálnak fel, amit a hazai közigazgatás-szervezési gyakorlatban eddig még nem használtunk ki kellőképpen. A kilencvenes évek végére a hatályos magyar szabályozás ,rögzülésével” több nyitott kérdés megválaszolatlanul maradt, például a területfejlesztési társulások, a körjegyzőségek vagy a városi vonzáskörzetek szerepe, besorolása, szabályozása. A magyar községek közigazgatási beosztásának, együttmüködési gyakorlatának történeti áttekintése jól felvezeti a jelenlegi rendszer hibáit, több olyan integrációs formát is felvonultatva, amelyek a rendszerváltást megelöző két politikai rendszerben megfelelő választ jelentettek az akkori kihívásokra.

A nemzetközi kitekintésben kiemelt figyelmet kap a német jogrendszeren belüli önkormányzati együttműködési gyakorlat, melynek indokaként a magyar-német jogtörténeti párhuzamot hozza fel a szerzö. Az újraegyesítés utáni német közigazgatás-szervezési problémák felvonultatása ráadásul nem csak egy harmonizált igazgatáskörzetesítésre, de egy volt szocialista ország közigazgatási rendszerének integrációs nehézségeire is mintául szolgálhatnak.

Áttérve a hazai helyzet elemzésére a szerzö a társulási tradíciók hiányában, az önkormányzati együttmüködések szabályozatlanságában, koncepcionális tisztázatlanságában látja a rendszerváltás utáni települési kooperációk kialakulásának legfőbb gátját. Az alkotmányban deklarált társulási szabadság elve ellent mond a fejlett európai országok gyakorlatának, ráadásul a rendszerváltás egy szétaprózott helyi önkormányzati rendszert hozott létre, ahol az önállóság eufóriájában élő lokális önkormányzatok nem is gondoltak a célszerü és hatékony együttmüködések kialakítására. A közigazgatási gyakorlat a kilencvenes évek elején aztán egyre több igazgatás-szervezési és hatékonysági kérdést vetett fel, ám az önkormányzati törvény módosítása, valamint a társulási törvény hatályba lépése csak részleges megoldást jelentett a problémákra. 
Eszmefuttatásai során a szerző azon véleményének ad hangot, hogy a kötelezö társulások intézményének átgondolt és szabályozott bevezetése elengedhetetlen lenne Magyarországon. Ideális esetben ez a lépés csak kis mértékben korlátozná a községi önállóságot, és garantálná a széles feladat- és hatáskör fennmaradását a helyi önkormányzatok számára, valamint hozzájárulna a rendszer hatékonyságának növekedéséhez és az alsó fokú közigazgatás szakszerủ müködéséhez. „Mindezek alapján a kötelező társulás az önkormányzatok társulási szabadságát korlátozó olyan intézmény” lenne, amely „az államszervezet egységéhez és az önkormányzati autonómia megörzéséhez füződó érdek közötti egyensúly megteremtésére hivatott." (122. o.) Történjen az intézmény bevezetése - a feladat típusától függően - akár az állami felügyeleti szerv hatáskörébe utalva, akár a törvényhozó részletes, pontos szabályozásának kitéve.

Az önkormányzati társulások egységes és komplex szerkezetủ nyilvántartási rendszerének hiányában a szerzö zömében esettanulmányok segítségével, Baranya megye példáján keresztül elemzi a társulások helyzetét, ami színesíti, gazdagítja a tanulmány tartalmát, bővíti annak információs- és adatbázisát. A szerző - aprólékos kutatómunkája zárásaként - meglepö, érdekes és fontos összefüggésekre hívja fel az olvasók figyelmét. Nyomon követhetjük például a Baranya megyei körjegyzőségek, önkormányzati társulások és területfejlesztési társulások fejlödéstơrténetét, a kistérségek körüli bonyodalmak alakulását.

Központi kérdés a finanszírozás, hiszen a társulások feladatellátásához szükséges pénzügyi háttér megteremtése több szinten is felboríthatja a jelenlegi finanszírozási gyakorlatot: az önkormányzatok teljes költségvetése változtatást igényel, átgondolásra szorul a térségi szerepkör értelmezése és finanszírozása, fennáll a területpolitikai differenciálás beiktatásának lehetősége stb.

A rendszerváltáskor létrehozott közigazgatási rendszerünk feluilvizsgálata, a magyar közigazgatás modernizálása mind a területi, mind pedig a helyi önkormányzati szinten elkerülhetetlen. A szerző három fö pontban foglalja össze a települési önkormányzatok helyzetét érintö reform pilléreit: a feladat- és hatáskör kérdéskörét, az állami felügyelet problematikáját és a finanszírozás kulcsterületét emelve ki a javaslatok halmazából. Nem véletlen, hogy éppen az integráció kérdésével foglalkozó könyv lapjain köszönnek vissza a fenti problémák, hiszen az önkormányzati együttmúködések kérdése elválaszthatatlanul kapcsolódik hozzájuk.

A közigazgatási reform végrehajtásához a szerző szükségesnek tartja az államönkormányzat viszony alkotmányos „(újra)szabályozását”, valamint rögzíteni kell az állam helyi ügyekbe történỏ beavatkozásának határait, az ország bármely településén élö állampolgárok alapjogait a közszolgáltatások területén stb.

Fontos kérdés, hogy két- vagy háromszintủ területi közigazgatási struktúra mellett teszik-e le a voksukat a döntéshozók, hiszen az államigazgatási körzetek kialakításával, a körzetesítés által érintett feladatkörök bövülésével az állam már jelezte, a kétszintủ igazgatási struktúra keretei - bizonyos esetekben - szükösek. A fokozódó állami jelenlét a megyei és a települési szint között olyan hatékonysági lépések sorozatának tekinthetó, amely nem a horizontális koncentráció eszközével keres 
megoldást a problémákra. A szerzö ugyanakkor felhívja a figyelmet arra, hogy a körzetközponti igazgatás túlzottan elaprózott, de ez a hiba egy egységes - például a statisztikai kistérségi léptékre létre hozott - alsó fokú igazgatási körzet bevezetésével orvosolható lenne.

A közigazgatás decentralizációjának lehetséges forgatókönyvei közül tehát a politikai döntéshozók döntik el, hogy melyik fog megvalósulni. Rajtuk áll, hogy lesznek-e regionális önkormányzatok, milyen szerep jut a települési önkormányzatoknak, és ezzel együtt milyen integrációs törekvéseknek kell feltétlenül a rendszerbe épülniük stb. A döntés kimenetelétỏl függetlenül megállapítható azonban, hogy melyek azok a koncepcionális jogalkotási elemek, amelyek megoldásra várnak. A szerzö a könyv összegzéseként pontokba szedve gyüjti össze ezeket a feladatokat, továbbá javaslatot fogalmaz meg az önkormányzati társulások szabályozásának irányára. Felhívja a figyelmet az önkormányzati integráció egyik lehetséges formájának, a városkörnyéki igazgatás bevezetésének célszerüségére.

Somlyódyné Pfeil Edit zárszavában felveti, hogy a kitüzött feladat - a közigazgatás korszerüsítése - hatalmas, de hozzáteszi, hogy ,az önkormányzati közigazgatás jövőképe és jövője csak a magyar állam területi struktúrájának átalakulásához kötötten nyerhet értelmet. A végrehajtásban az önkormányzati kapcsolatoknak és intézményesülésüknek kiemelkedő szerep fog jutni. E folyamatban a kooperáció és a partnerség elve meghatározó jelenségüvé válik". (280. o.) E változási irányokat felismerve született meg a könyv, amely segítséget nyújthat a hatalmas feladat megoldásához, az önkormányzati integrációs lehetöségek megismeréséhez. 